\title{
Electrolytic Properties and Application to a Lithium Battery of Ternary Solvent Electrolytes with Ethylene Carbonate - Dimethyl Carbonate-3-Methylsydnone and 3-Ethylsydnone
}

\author{
Yukio SASAKI,* Hayato MIURA, Kazuhiro TOMINAGA, and Noritoshi NANBU
}

Department of Applied Chemistry, Faculty of Engineering, Tokyo Institute of Polytechnics (1583 Iiyama, Atsugi, Kanagawa 243-0297, Japan)

\author{
Received September 5, 2001 ; Accepted February 21, 2002
}

\begin{abstract}
The electrolytic conductivity and charge-discharge characteristics of the lithium electrode were examined in ternary solvent systems made up of an ethylene carbonate (EC)-dimethyl carbonate (DMC) equimolar binary mixture with 3 methylsydnone (3-MSD) and 3-ethylsydnone (3-ESD). The electrolytes used were $\mathrm{LiClO}_{4}, \mathrm{LiPF}_{6}, \mathrm{LiBF}_{4}, \mathrm{LiCF}_{3} \mathrm{SO}_{3}, \mathrm{LiN}$ $\left(\mathrm{CF}_{3} \mathrm{SO}_{2}\right)_{2}$, and $\mathrm{LiN}\left(\mathrm{C}_{2} \mathrm{~F}_{5} \mathrm{SO}_{2}\right)_{2}$. The order of the decrease in conductivity of the ternary solvent electrolytes at a mol ratio 0.5 of $3-\mathrm{MSD}$ and $3-\mathrm{ESD}$ was $\mathrm{LiPF}_{6}>\mathrm{LiClO}_{4}>\mathrm{LiN}\left(\mathrm{CF}_{3} \mathrm{SO}_{2}\right)_{2}>\mathrm{LiN}\left(\mathrm{C}_{2} \mathrm{~F}_{5} \mathrm{SO}_{2}\right)_{2}>\mathrm{LiBF}_{4}>\mathrm{LiCF}_{3} \mathrm{SO}_{3}$. The $1 \mathrm{~mol}$ $\mathrm{dm}^{-3} \mathrm{LiN}\left(\mathrm{CF}_{3} \mathrm{SO}_{2}\right)_{2}$ and $\mathrm{LiN}\left(\mathrm{C}_{2} \mathrm{~F}_{5} \mathrm{SO}_{2}\right)_{2}$ electrolytes with large anions showed moderate conductivities of higher than $6-7 \mathrm{mS} \mathrm{cm}^{-1}$ at a mol ratio 0.5 of 3-MSD and 3-ESD. Addition of 3-MSD and 3-ESD to the EC-DMC equimolar binary mixtures containing $\mathrm{LiClO}_{4}, \mathrm{LiBF}_{4}, \mathrm{LiCF}_{3} \mathrm{SO}_{3}$, and $\mathrm{LiN}\left(\mathrm{CF}_{3} \mathrm{SO}_{2}\right)_{2}$ is effective for raising lithium electrode cycling efficiency. We found by using scanning electron microscope (SEM) that the cycling efficiency is dependent on the dendrite formation and the morphology of the film formed on the Ni (working) electrode.
\end{abstract}

Key Words : Lithium Batteries, Sydnone Compounds, Cycling Efficiency, Scanning Electron Microscope

\section{Introduction}

A sydnone compound is well known as a typical mesoionic compound, which can not be satisfactorily represented by any one canonical structure. ${ }^{1-3)}$ This unique structure leads to a large dipole moment ${ }^{4,5)}$ and high dielectric constants ${ }^{6-9)}$ compared with those of other organic solvents. Especially, 3-methylsydnone (3MSD) and 3-ethylsydnone (3-ESD) (Fig. 1) among the 3alkylsydnones have high dielectric constants, 144.0 $\left(40^{\circ} \mathrm{C}\right)^{6,7)}$ and $102.3\left(25^{\circ} \mathrm{C}\right){ }^{10)}$ respectively. However, it is preferable to use mixed solvents of these sydnones and a low viscosity solvent as the overall solvent for electrolytes because of the high viscosity of the sydnones. We have already reported that the mixed solvents of 3 propylsydnone with tetrahydrofuran (THF) and 1,2dimethoxyethane (DME) were favorable solvents for electrolytes. ${ }^{11,12)}$ In previous papers, ${ }^{12-14)}$ the electrolytic

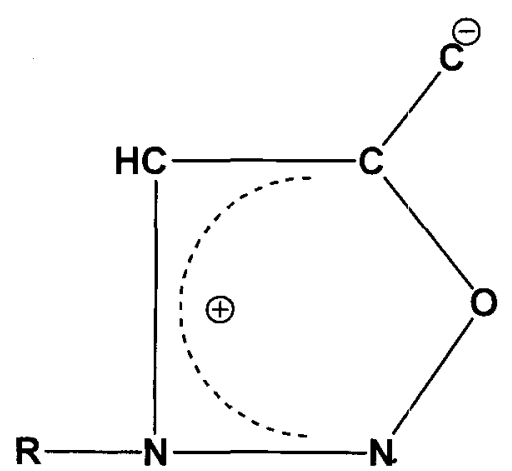

Fig. 1 Structure of 3-alkylsydnone. 3-MSD $\left(\mathrm{R}=\mathrm{CH}_{3}\right)$, 3-ESD $\left(\mathrm{R}=\mathrm{C}_{2} \mathrm{H}_{5}\right)$. properties and application to lithium batteries of binary mixtures with some 3-alkylsydnones and low viscosity solvents have been examined based on the conductivity and the lithium electrode cycling efficiency.

The purpose of the present study is to elucidate the electrolytic behavior and charge-discharge characteristics of the lithium electrode in the ternary solvent systems of ethylene carbonate (EC)-dimethyl carbonate (DMC) equimolar binary solvent mixture, which is a typical mixed solvent for lithium batteries, with 3-MSD and 3ESD.

\section{Experimental}

\section{1 Apparatus and measurements}

Conductivities of the electrolytes were measured using a conductometer (Toa Electronics, Model CM-60S) with a cell (Model CGT-511B). By use of a charge/discharge unit (Hokuto Denko, Model HJ-201B), the lithium electrode cycling efficiency was estimated by a galvanostatic plating-striping method which was reported by Koch and Brummer. ${ }^{15)}$ The preparation of the electrolyte solutions and the cell assembly were carried out in an Ar-filled dry box. The morphology of the films formed on the $\mathrm{Ni}$ (working) electrode after cycling was examined by using a scanning electron microscope (SEM, JSM-5310).

\section{2 Materials}

The synthesis of 3-ethylsydnone (3-ESD), starting with ethyl bromoacetate and ethylamine, was carried out essentially using the literature procedure. ${ }^{6,16,17)}$ Commercial sarcosine (N-methylglycine), which is an intermediate 
product of 3-methylsydnone (3-MSD), was used as a starting material for the synthesis of 3-MSD. The purity and structure were confirmed by elemental analysis and $\mathrm{C}-\mathrm{H}$ COSY NMR. Commercial reagent grade ethylene carbonate (EC), diethyl carbonate (DEC), and sydnones were dehydrated using purified molecular sieves $(4 \AA)$ before preparation of the solutions. Commercial reagent grade $\mathrm{LiPF}_{6}, \mathrm{LiBF}_{4}, \mathrm{LiClO}_{4}$, and $\mathrm{LiCF}_{3} \mathrm{SO}_{3}$ were dried in vacuo for $24 \mathrm{~h}$ at $70^{\circ} \mathrm{C}$. Commercial reagent grade $\mathrm{LiN}$ $\left(\mathrm{CF}_{3} \mathrm{SO}_{2}\right)_{2}$ and $\mathrm{LiN}\left(\mathrm{C}_{2} \mathrm{~F}_{5} \mathrm{SO}_{2}\right)_{2}$ were dried in vacuo for 24 $\mathrm{h}$ at $150^{\circ} \mathrm{C}$.

\section{Results and Discussion}

The variation of specific conductivities in ternary solvent electrolyte solutions by the addition of 3-MSD to the EC-DMC equimolar binary mixture containing $1.0 \mathrm{~mol}$ $\mathrm{dm}^{-3}$ electrolytes at $25^{\circ} \mathrm{C}$ is shown in Fig. 2. The conductivities in $\mathrm{LiPF}_{6}, \mathrm{LiClO}_{4}, \mathrm{LiN}\left(\mathrm{CF}_{3} \mathrm{SO}_{2}\right)_{2}$, and $\mathrm{LiN}\left(\mathrm{C}_{2} \mathrm{~F}_{5} \mathrm{SO}_{2}\right)_{2}$ electrolytes gradually decrease with increasing 3-MSD concentration with higher viscosity. For $\mathrm{LiBF}_{4}$ and $\mathrm{LiCF}_{3} \mathrm{SO}_{3}$ electrolytes, the addition of 3-MSD affects scarcely the conductivities. The conductivities of these electrolytes seem to be more significantly influenced by the viscosity rather than the dielectric constant of the solution due to the addition of 3-MSD. ${ }^{6}$ The order of the decrease in conductivities of the electrolytes at mol ratio 0.5 of 3 -MSD is $\mathrm{LiPF}_{6}>\mathrm{LiClO}_{4}>\mathrm{LiN}\left(\mathrm{CF}_{3} \mathrm{SO}_{2}\right)_{2}>$ $\mathrm{LiN}\left(\mathrm{C}_{2} \mathrm{~F}_{5} \mathrm{SO}_{2}\right)_{2}>\mathrm{LiBF}_{4}>\mathrm{LiCF}_{3} \mathrm{SO}_{3}$. The moderate conductivities of $\mathrm{LiN}\left(\mathrm{CF}_{3} \mathrm{SO}_{2}\right)_{2}$ and $\mathrm{LiN}\left(\mathrm{C}_{2} \mathrm{~F}_{5} \mathrm{SO}_{2}\right)_{2}$ with a large anion as well as $\mathrm{LiClO}_{4}$ are dependent on the resonance structure ${ }^{18)}$ of the $\mathrm{N}\left(\mathrm{CF}_{3} \mathrm{SO}_{2}\right)_{2}{ }^{-}$and $\mathrm{N}\left(\mathrm{C}_{2} \mathrm{~F}_{5} \mathrm{SO}_{2}\right)_{2}{ }^{-}$ions. This means that the resonance structure contributes to stabilization of the $\mathrm{N}\left(\mathrm{CF}_{3} \mathrm{SO}_{2}\right)_{2}{ }^{-}$and $\mathrm{N}\left(\mathrm{C}_{2} \mathrm{~F}_{5} \mathrm{SO}_{2}\right)_{2}{ }^{-}$ions. This electrolytic behavior is similar to that in the 3-ESD system.

Figure 3 shows the lithium electrode cycling efficiencies (charge-discharge characteristics of lithium electrode) in ternary solvent electrolytes by the addition of 3MSD to the EC-DMC equimolar binary mixture contain-

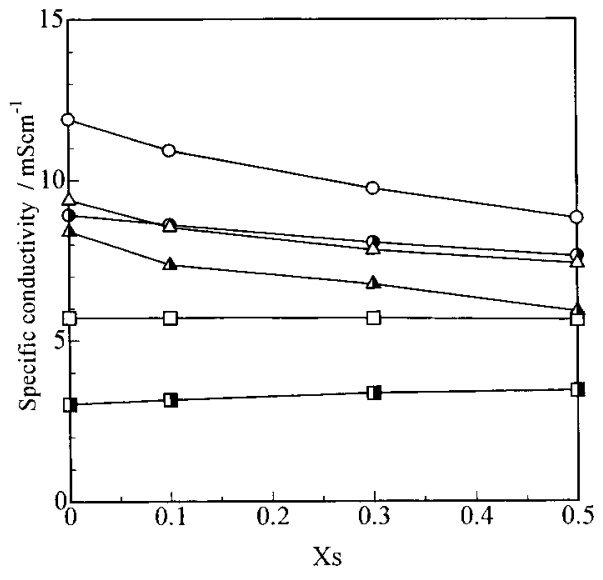

Fig. 2 Specific conductivities in ternary solvent electrolyte solutions by the addition of 3-MSD to the EC-DMC equimolar binary mixture containing $1.0 \mathrm{~mol} \mathrm{dm} \mathrm{dm}^{-3}$ electrolyte at $25^{\circ} \mathrm{C}$. $\mathrm{X}_{\mathrm{S}}$ means the mol ratio of 3-MSD given in EC-DMC-3-MSD (1: $1: \mathrm{X}_{\mathrm{S}}$ mol ratio). (O): $\mathrm{LiPF}_{6},(()): \mathrm{LiClO}_{4},(\square): \mathrm{LiBF}_{4}$, (口): $\mathrm{LiCF}_{3} \mathrm{SO}_{3},(\triangle): \mathrm{LiN}\left(\mathrm{CF}_{3} \mathrm{SO}_{2}\right)_{2},(\boldsymbol{\Lambda}): \mathrm{LiN}\left(\mathrm{C}_{2} \mathrm{~F}_{5} \mathrm{SO}_{2}\right)_{2}$.

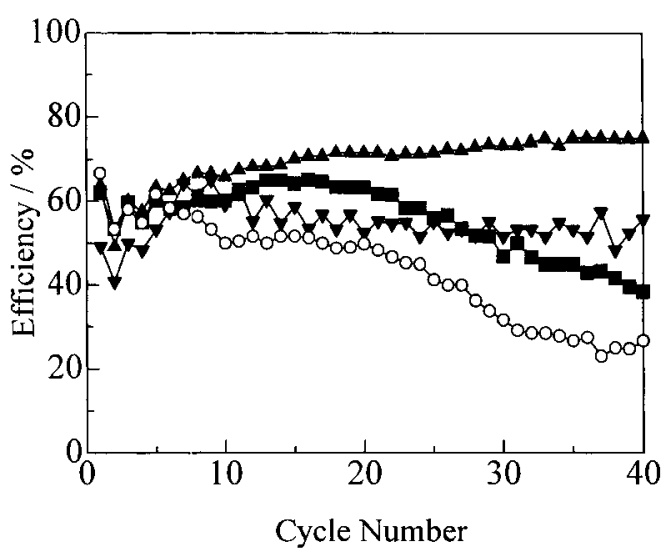

Fig. 3 Lithium electrode cycling efficiencies in ternary solvent electrolytes by the addition of 3-MSD to the EC-DMC equimolar binary mixture containing $1.0 \mathrm{~mol} \mathrm{dm}{ }^{-3} \mathrm{LiClO}_{4}$ at $25^{\circ} \mathrm{C}$. (O): EC-DMC (mol ratio $1: 1$ ), (A): EC-DMC-3-MSD

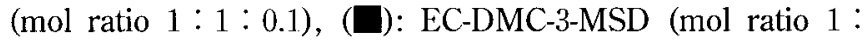
$1: 0.3),(\boldsymbol{\nabla}):$ EC-DMC-3-MSD (mol ratio $1: 1: 0.5$ ).
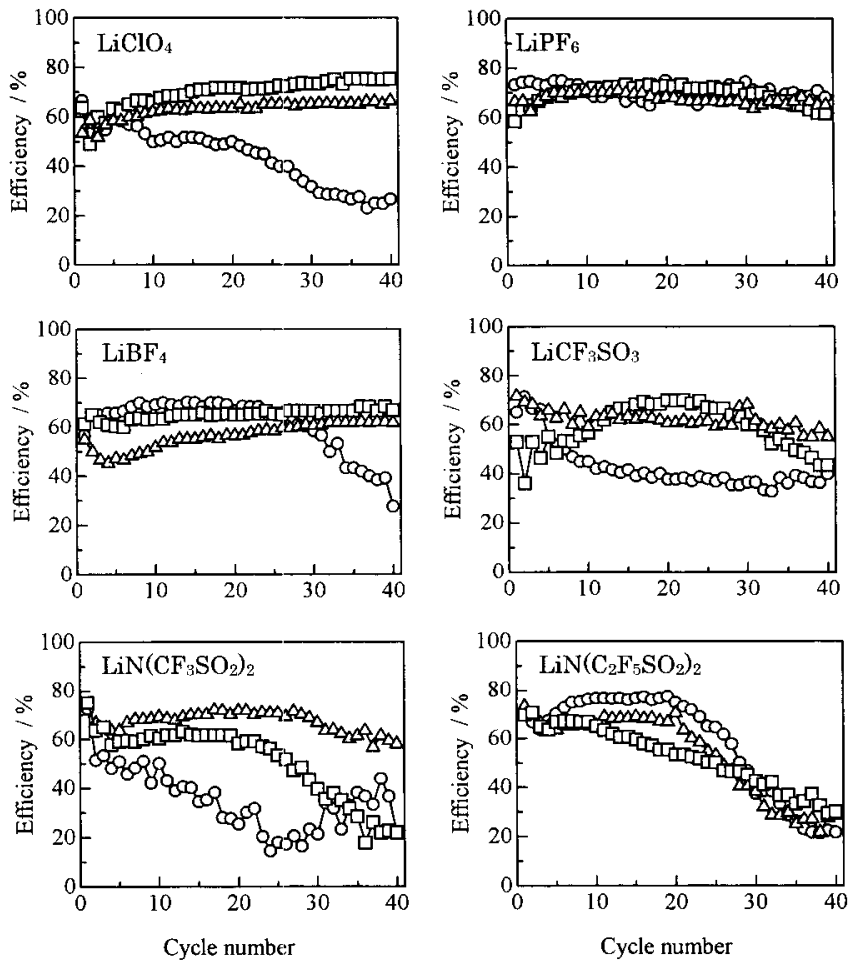

Fig. 4 Lithium electrode cycling efficiencies in ternary sol-

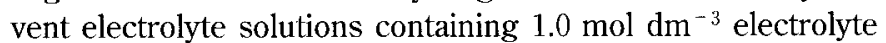
at $25^{\circ} \mathrm{C} .(\mathrm{O})$ : EC-DMC (mol ratio $\left.1: 1\right)$, ( $\square$ ): EC-DMC-3MSD (mol ratio $1: 1: 0.1),(\triangle)$ : EC-DMC-3-ESD (mol ratio $1: 1: 0.1)$.

ing $1.0 \mathrm{~mol} \mathrm{dm}^{-3} \mathrm{LiClO}_{4}$. It is found that the cycling efficiencies in these solutions become higher at mol ratio 0.1 of 3-MSD and 3-ESD. The cycling efficiencies in ternary solvent electrolytes at mol ratio 0.1 of 3-MSD and 3ESD containing $1.0 \mathrm{~mol} \mathrm{dm}^{-3}$ each lithium salt are shown in Fig. 4. In Fig. 4, an addition of 3-MSD and 3ESD to the EC-DMC equimolar binary mixtures containing $\mathrm{LiClO}_{4}, \mathrm{LiBF}_{4}, \mathrm{LiCF}_{3} \mathrm{SO}_{3}$, and $\mathrm{LiN}\left(\mathrm{CF}_{3} \mathrm{SO}_{2}\right)_{2}$ is effective for raising the cycling efficiency. On the other hand, the addition effect to the $\mathrm{LiPF}_{6}$ electrolyte is minor. However, the cycling efficiency in $\mathrm{LiPF}_{6} /$ EC-DMC-3-MSD is 
(a) $\mathrm{LiClO}_{4}$
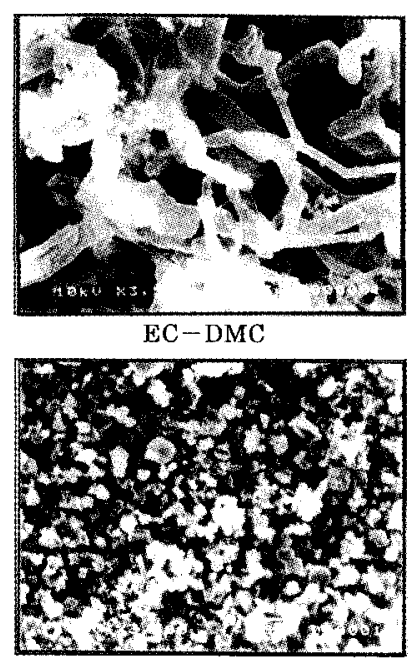

$\mathrm{EC}-\mathrm{DMC}-3-\mathrm{MSD}(1: 1: 0.1)$

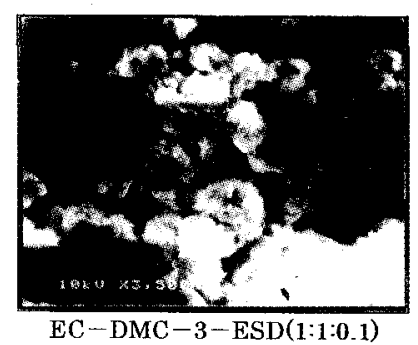

(b) $\operatorname{LiN}\left(\mathrm{C}_{2} \mathrm{~F}_{5} \mathrm{SO}_{2}\right)_{2}$
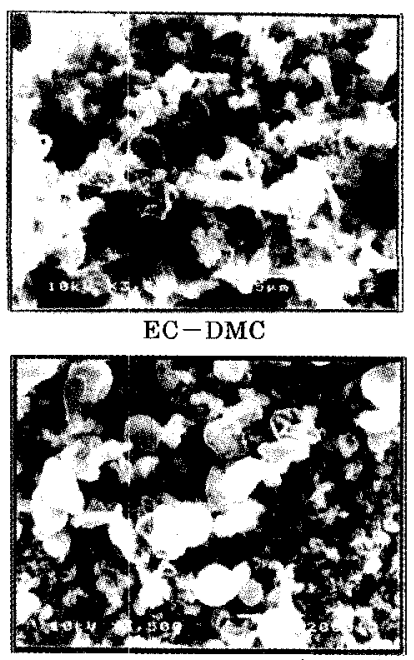

$\mathrm{EC}-\mathrm{DMC}-3-\mathrm{MSD}(1: 1: 0.1)$

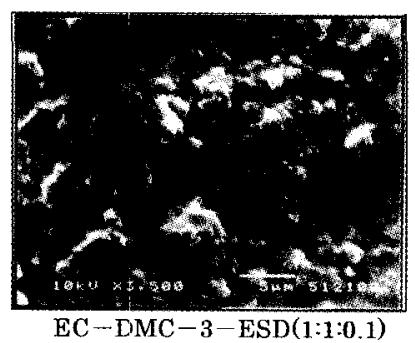

Fig. 5 SEM photographs of the Ni electrode (working) in EC-DMC, EC-DMC-3-MSD, and EC-DMC-3-ESD systems containing $1.0 \mathrm{~mol} \mathrm{dm}^{-3} \mathrm{LiClO}_{4}$ and $\mathrm{LiN}\left(\mathrm{C}_{2} \mathrm{~F}_{5} \mathrm{SO}_{2}\right)_{2}$ after the 40 th cycle.

lower than that in $\mathrm{LiClO}_{4} / \mathrm{EC}-\mathrm{DMC}-3-\mathrm{MSD}$ at the 40 th $\mathrm{cy}$ cle. Figure 5 shows the scanning electron microscope (SEM) photographs of the Ni working electrode in ECDMC and EC-DMC-3-MSD systems containing $1.0 \mathrm{~mol}$ $\mathrm{dm}^{-3}$ (a) $\mathrm{LiClO}_{4}$ and (b) $\mathrm{LiN}\left(\mathrm{C}_{2} \mathrm{~F}_{5} \mathrm{SO}_{2}\right)_{2}$ after the 40th cycle. The formation of the lithium dendrite is appreciably observed in the $\mathrm{LiClO}_{4} / \mathrm{EC}-\mathrm{DMC}$ electrolyte. On the contrary, the dendrite formation in $\mathrm{LiClO}_{4} / \mathrm{EC}-\mathrm{DMC}-3-\mathrm{MSD}$ and $\mathrm{LiClO}_{4} / \mathrm{EC}$-DMC-3-ESD electrolytes is scarcely observed. In addition, the film on the electrode surface in $\mathrm{LiClO}_{4} /$ EC-DMC-3-MSD electrolyte is significantly homogeneous and consists of an uniform grain size. However, the formation of lithium dendrite is not observed in ECDMC, EC-DMC-3-MSD, and EC-DMC-3-ESD electrolytes containing $\mathrm{LiN}\left(\mathrm{C}_{2} \mathrm{~F}_{5} \mathrm{SO}_{2}\right)_{2}$ as shown (b) in Fig 5 . Further-

more, the film in the $\mathrm{LiN}\left(\mathrm{C}_{2} \mathrm{~F}_{5} \mathrm{SO}_{2}\right)_{2} / \mathrm{EC}$-DMC-3-MSD electrolyte is considerably heterogeneous compared with that in the $\mathrm{LiClO}_{4} / \mathrm{EC}$-DMC-3-MSD electrolyte. Accordingly, it is thought that the lithium electrode cycling efficiency is dependent on the dendrite formation and the morphology of the film formed on the electrode.

In conclusion, addition of 3-MSD and 3-ESD to the ECDMC equimolar binary mixtures containing $\mathrm{LiClO}_{4}$, $\mathrm{LiBF}_{4}, \mathrm{LiCF}_{3} \mathrm{SO}_{3}$, and $\mathrm{LiN}\left(\mathrm{CF}_{3} \mathrm{SO}_{2}\right)_{2}$ is effective for raising cycling efficiency. Especially, the addition of 3-MSD for mol ratio 0.1 to EC-DMC equimolar binary mixture containing $\mathrm{LiClO}_{4}$ is useful for obtaining higher efficiency at a higher cycle number range.

\section{References}

1) W. Baher, W. D. Ollis, and V. D. Poole, J. Chem. Soc., $1949,307$.

2) W. Baher and W. D. Ollis, Quant. Rev. (London), 11, 15 (1957).

3) F. H. C. Stewart, Chem. Rev., 64, 129 (1964).

4) R. A. W. Hill and L. E. Sutton, J. Chem. Soc., 1949, 746.

5) G. H. Schmid, J. Mol. Struct., 5, 236 (1970).

6) R. J. Lemire and P. G. Sears, J. Chem. Eng. Data, 22, 376 (1977).

7) R. J. Lemire and P. G. Sears, J. Solution Chem., 9, 553 (1980).

8) Y. Sasaki and Y. Ishibashi, Bull. Chem. Soc. Jpn., 63, 1422 (1990).

9) Y. Sasaki, I. Komiya, and M. Handa, Bull. Chem. Soc. Jpn., 67, 2571 (1994).

10) M. Handa, T. Suzuki, H. Fukuda, and Y. Sasaki, Chem. Lett., 1998, 457.

11) Y. Sasaki, K. Miyagawa, N. Wataru, and H. Kaido, Bull. Chem. Soc. Jpn., 66, 1608 (1993).

12) Y. Sasaki, M. Ohashi, S. Okahata, H. Kaido, T. Mori, and M. Handa, Nippon Kagaku Kaishi, 1993, 1217.

13) Y. Sasaki, K. Sekine, and M. Handa, Prog. Batteries \& Battery Materials, 17, 239 (1998).

14) S. Iinou, M. Handa, and Y. Sasaki, Electrochemistry, 67, 22 (1999).

15) V. R. Koch and S. B. Brummer, Electrochim. Acta, 23, 55 (1978).

16) L. B. Kier and D. Dhawan, J. Pharm. Sci., 51, 1058 (1962).

17) V. F. Vasil' eva and V. G. Yashunskii, J. Gen. Chem. USSR (Engl. Transl.), 32, 2845 (1962).

18) A. Webber, J. Electrochem. Soc., 138, 2586 (1991). 